\title{
A NEW NATIONALISM IN SOUTHEAST ASIA
}

The effects flowing from the financial crisis of 2008 are still with us. Europe is trying, with much difficulty, to straighten its financial affairs while the US has had to weather stop-start efforts to do the same. The news from the financial centres is grim, at best. Asia, meanwhile, seems to show some resilience but even here Japan appears to continue with its long struggle to reform its economy. In recent months China has also begun to suffer from the effects of the downturn in the West.

Amidst this state of affairs, Southeast Asia seems to be doing better than most. Many reasons have been posited for this state of affairs including the role that China has played in the region by being a buyer of commodities. But the history of economic growth in Southeast Asia also points to the fact that it had weathered a financial crisis of its own in 1997. Lessons were learnt at that time. Some of those lessons have been instructive.

An excessive reliance on financial markets and portfolio flows was dampened as countries in the region became wary of funds and fund managers. The 1997 crisis began with the loss of confidence in the Thai currency and the Thai economy and then spilled over to the rest of the region. Malaysia instituted capital controls for a time while it restructured its economy. Indonesia had to be bailed out by the International Monetary Fund. In all three countries political changes followed from the impact of the financial crisis. In Thailand, new political actors became active with the rural population becoming a determining feature of the political landscape. The cleavage between the urbanised middle class and the rural population became more stark as power shifted between different parties - the red and yellow shirts. This shifting political movement has not ended. It continues to dominate the Thai political landscape.

In Malaysia, while there was no political instability as such, the party in power had to weather internal dissension over the decision to institute capital controls. In the event, those in favour of broad-based IMF reforms 
rather than capital controls were eased out. The effects of that decision are now more apparent. It gave birth to a coalition of opposition parties with a leadership to match. The following elections brought more opposition members into parliament, and the loss of several states within the Federation to opposition parties. This was a new phenomenon in a country which, for a long time, had been held together by an older and more established political constellation. New lessons in creating a different political architecture were being learnt.

Indonesia was the country which suffered most in the aftermath of the 1997 crisis. The Soeharto regime which had been in power for over thirty years and which had overseen the transformation of the country fell from grace. There were popular calls for democracy and devolution of power. Constitutional changes were drafted, new elections were called and the power of the military was curtailed. Civilian presidents came into office and efforts at political and administrative devolution were put into effect. A new constellation of power centres across the archipelago became visible. No longer was the centre in Jakarta the only power to wield control over the provinces. The provincial authorities, newly imbued with legislative and revenue sharing arrangements, became power centres in their own right. Where it was once possible to negotiate investment or business arrangements for a province through
Jakarta it now became essential for all such discussions to take place at both local and central levels with the final say being instituted by the province itself. The impact of this change brought about by political devolution was the proliferation of political parties, and the emergence of new business leaders in the provinces. At the heart of these changes in Indonesia lay the sense that something had to be done to improve the lot of the population. The economy turned inward. Exportled production was downplayed when Indonesian companies could not afford to import materials for manufacturing as the currency went into a downward spiral. The response was swift. The Indonesian business community began to use local materials to produce for the domestic economy. While oil and gas and commodities continued to be exported, manufacturing refocused itself on the domestic consumer.

The success of both political devolution and economic restructuring gave rise to a sense of economic nationalism that has lasted till now. As an indicator, the economy quadrupled in size between 2000 and 2010 in nominal terms. This confidence in its own abilities has been characteristic of the Indonesian experiment in democracy and economic development of the last decade.

Thus the recent financial crisis in the West, while having an impact on the region, has been somewhat ameliorated by the structural changes that the region undertook after its own crisis in 1997. Domestic demand has cushioned the 
loss of export markets while more prudent supervision of portfolio flows has prevented the excesses seen elsewhere. Countries such as Singapore, which have a small population and a narrow domestic demand base, continue to be effected by the vagaries of the US and European financial crisis. Likewise, countries such as Vietnam which are dependent on manufactured exports are now having to negotiate through the effects of slow or stalling demand in the West. Thailand, however, is an unusual story. When the 1997 financial crisis unfolded, the urban population diffused into the rural sector as it did during previous economic downturns. The social construct of Thai society with its porous movement between the urban and rural populations has been its saviour, allowing the newly impoverished urbanised workers to melt into the rural economy.

In the larger countries of Southeast Asia, the size of domestic demand has been instrumental in cushioning the effects of the current recession. The lessons of the 1997 financial crisis have now been learnt. Self-reliance has become more apparent and with it, a renewed national consciousness. In Thailand, for example, the social and economic effects of the floods which destroyed manufacturing facilities last year have been rapidly overcome as the country set about remedying the flood defences and getting operations back on track. In Indonesia, the nationalist streak has expanded considerably as the provinces and the centre have become more confident of their capabilities to focus on the challenges of development. Well trained and qualified private sector managers have been co-opted into senior decision-making positions within the government and they have given a confidence boost to national interests. In Malaysia, for example, the development of the southern tip of the peninsular bordering Singapore, in an area known as Iskandar Malaysia, there is a strong sense of competing against Singapore with Malaysian capabilities equal to that of the neighbour.

At the subregional level, the 1997 crisis laid bare the disjoints in the Association of Southeast Asian Nations (Asean). Indonesia, which was the anchor country in the arrangement, became pre-occupied with resolving its own future. At the same time it became clear that the group could not help individual countries weather the financial meltdown. The reasons for the creation of a single economic zone fell apart when political pressures to address national concerns came to the fore. Soon after, the chasm between the original founding members (Indonesia, Malaysia, Brunei, Thailand, Singapore and the Philippines) and the new members (Cambodia, Laos, Vietnam and Myanmar) became apparent when a need for a staggered integration process had to be designed. This allowed for a longer time for the lesser developed new members to restructure and grow their economies before becoming a full part of the Asean community. But fissures continue to fester as the role 
of China within the region has shown. At the recent Asean meeting in Phnom Penh in September, for the first time, the community could not issue a joint statement because of the territorial disputes that the Philippines and Vietnam had with China. It now appears that national interests have become more important than regional ones, and China has sought to exploit this structural impasse in its relations with the Asean community.

But these nationalist sentiments are not necessarily squared against globalization. They have augmented a long underlying sense that the different ethnic groups in Southeast Asia can, with the right capabilities, manage their own affairs. In many ways, the new nationalism and its associated confidence are fruits of what Dr Mahathir Mohamad, the former Malaysian prime minister, had tried to create in Malaysia. The paradox of this state of affairs is that it has come about as a result of a crisis brought about by a western model of capitalism that has lost its moral compass. A model that many in the region had been forced to accept as part of the «Washington consensus». So now in the present recession, with China and India both suffering from the effects of declining demand in the West, Southeast Asia is applying the bitter lessons learnt at an earlier time - to become more selfreliant. Perhaps that is the new term for economic nationalism?

Sree Kumar Director de Sreekumar Siddique \& Co, Singapur. 